\title{
Absolute density measurements of ammonia produced via plasma-activated catalysis
}

\section{Citation for published version (APA):}

Vankan, P. J. W., Rutten, T., Mazouffre, S., Schram, D. C., \& Engeln, R. A. H. (2002). Absolute density measurements of ammonia produced via plasma-activated catalysis. Applied Physics Letters, 81(3), 418-420. https://doi.org/10.1063/1.1494104

DOI:

10.1063/1.1494104

Document status and date:

Published: 01/01/2002

\section{Document Version:}

Publisher's PDF, also known as Version of Record (includes final page, issue and volume numbers)

\section{Please check the document version of this publication:}

- A submitted manuscript is the version of the article upon submission and before peer-review. There can be important differences between the submitted version and the official published version of record. People interested in the research are advised to contact the author for the final version of the publication, or visit the $\mathrm{DOI}$ to the publisher's website.

- The final author version and the galley proof are versions of the publication after peer review.

- The final published version features the final layout of the paper including the volume, issue and page numbers.

Link to publication

\section{General rights}

Copyright and moral rights for the publications made accessible in the public portal are retained by the authors and/or other copyright owners and it is a condition of accessing publications that users recognise and abide by the legal requirements associated with these rights.

- Users may download and print one copy of any publication from the public portal for the purpose of private study or research.

- You may not further distribute the material or use it for any profit-making activity or commercial gain

- You may freely distribute the URL identifying the publication in the public portal.

If the publication is distributed under the terms of Article 25fa of the Dutch Copyright Act, indicated by the "Taverne" license above, please follow below link for the End User Agreement:

www.tue.nl/taverne

Take down policy

If you believe that this document breaches copyright please contact us at:

openaccess@tue.nl

providing details and we will investigate your claim. 


\title{
Absolute density measurements of ammonia produced via plasma-activated catalysis
}

\author{
P. Vankan, T. Rutten, S. Mazouffre, ${ }^{\text {a) }}$ D. C. Schram, and R. Engeln ${ }^{\text {b) }}$ \\ Department of Applied Physics, Centre for Plasma Physics and Radiation Technology (CPS), Eindhoven \\ University of Technology, P.O. Box 513, 5600 MB Eindhoven, The Netherlands
}

(Received 2 January 2002; accepted for publication 21 May 2002)

\begin{abstract}
The generation of ammonia from atomic hydrogen and nitrogen has been demonstrated by means of cavity enhanced absorption spectroscopy. The atomic species are produced in a thermal plasma source in which plasma is created from mixtures of hydrogen and nitrogen. It is shown that for large atomic flux conditions, $2 \%$ of the hydrogen and nitrogen can be converted to ammonia. The process in which the ammonia molecules are formed from atomic radicals at the fully covered surface is called plasma-activated catalysis. (c) 2002 American Institute of Physics.
\end{abstract}

[DOI: $10.1063 / 1.1494104]$

In applications in which plasma is used for surface treatment or deposition, newly formed stable molecules are often detected in the background gas. It has been acknowledged for quite some time that plasma-surface interaction is of great importance in the production of these new stable molecules. For example, in 1975 Eremin $^{1}$ reported that the synthesis of ammonia was increased by a factor of 3, when platinum was used as a coating for the quartz wall of a plasma reactor in which discharges in $\mathrm{N}_{2}-\mathrm{H}_{2}$ mixtures were created. In high-frequency discharges it was reported in 1989 that zeolite added to the downstream plasma facilitated the ammonia production, which was ascribed to $\mathrm{NH}_{x}$ radicals adsorbed on the zeolite. ${ }^{2}$ We propose a different way of generating ammonia, i.e., via plasma-activated catalysis. In this process fluxes of hydrogen and nitrogen radicals are produced in a high density plasma source with high dissociation degree. The plasma then expands into a low pressure vessel, where most of the atomic radicals will arrive at the surface at which they will adsorb. At the surface new molecules can be generated which subsequently may desorb. In this way the dissociation in the plasma source is geometrically separated from the production of molecules from atomic constituents at the surface. This process can thus be called plasma-activated catalysis.

We here present absolute density measurements of ammonia produced in a vessel in which a plasma expands, which is created by a cascaded arc plasma source. ${ }^{3}$ In the cascaded arc a direct current generates a thermal plasma in mixtures of $\mathrm{N}_{2}$ and $\mathrm{H}_{2}$ at a typical pressure and power of 0.5 bar and $5 \mathrm{~kW}$, respectively. The arc is connected via a nozzle to a stainless steel vacuum vessel, which is kept at a pressure between 10 and $200 \mathrm{~Pa}$. From the nozzle the thermal plasma expands first supersonically and then after a stationary shock subsonically into the vessel.

The light source that has been used for the cavity enhanced absorption (CEA) measurements ${ }^{4}$ is a continuous

\footnotetext{
${ }^{a)}$ Present address: Laboratoire d'Aérothermique, CNRS, 1C, avenue de la Recherche Scientifique, 45071 Orléans, France.

b) Author to whom correspondence should be addressed; electronic mail: r.engeln@phys.tue.nl
}

wave diode laser, which is tunable in the $1520-1560 \mathrm{~nm}$ region. It has been used to perform open-path trace gas detection measurements ${ }^{5}$ and to study the ammonia spectrum in the $1.5 \mu \mathrm{m}$ region. ${ }^{6} \mathrm{~A}$ beam splitter directs $10 \%$ of the radiation into a reference cell, which is filled with 5 mbar of ammonia. The radiation that passes the beam splitter is coupled into a high finesse optically stable cavity with a length of $1.1 \mathrm{~m}$. The two plano-concave mirrors with a diameter of $25 \mathrm{~mm}$, a radius of curvature of $-1 \mathrm{~m}$ and reflectivity of $R=0.994$, are directly flanged onto the stainless steel vessel in which the plasma expands. To avoid optical feedback from the cavity to the laser, a Faraday isolator is used. During the experiments the laser is repeatedly scanned at a rate of $32 \mathrm{~Hz}$ over a spectral range of typically $1 \mathrm{~cm}^{-1}$. The light that leaks out of the cavity is detected by an InGaAs photodiode. The detector signal is amplified with a $0.1 \mathrm{~ms}$ rise time amplifier and displayed on one of the channels of a digital oscilloscope (10 bits, $300 \mathrm{MHz}$ ). A second channel is used to record simultaneously the signal of the photodiode behind the reference cell.

In Fig. 1 part of the CEA absorption spectrum of ammonia is shown as measured in the plasma reactor after 1000 averages, i.e., about $30 \mathrm{~s}$ of acquisition time. Of the four transitions that are shown in Fig. 1, three are reported by Lundsberg-Nielsen et al. ${ }^{7}$ with line positions, 6568.299, 6568.401 , and $6568.463 \mathrm{~cm}^{-1}$, and absorption coefficients, $7.556 \times 10^{-4}, 7.602 \times 10^{-4}$, and $0.948 \times 10^{-4} \mathrm{~cm}^{-1} \mathrm{Torr}^{-1}$, respectively. In the vertical direction the inverse of the timeintegrated intensity behind the cavity is plotted after subtraction of the base line. This relative absorption spectrum, expressed in loss of the empty cavity per round trip, i.e., $(1-R) / d$, can be put on an absolute scale by recording the CEA spectrum of a known amount of water. Using the transition strength ${ }^{8}$ and the known density of the ground-state water molecules, the factor $(1-R) / d$ is determined as $(5.5 \pm 0.5) \times 10^{-5} \mathrm{~cm}^{-1}$.

Three different experimental situations have been studied. However, the current through the arc is kept constant at 55 A during all experiments. For the first situation the nitrogen flows through the arc at a rate of $\phi_{\mathrm{N}_{2}}=2.0$ standard liters per minute (slm), thus delivering a substantially dissociated 


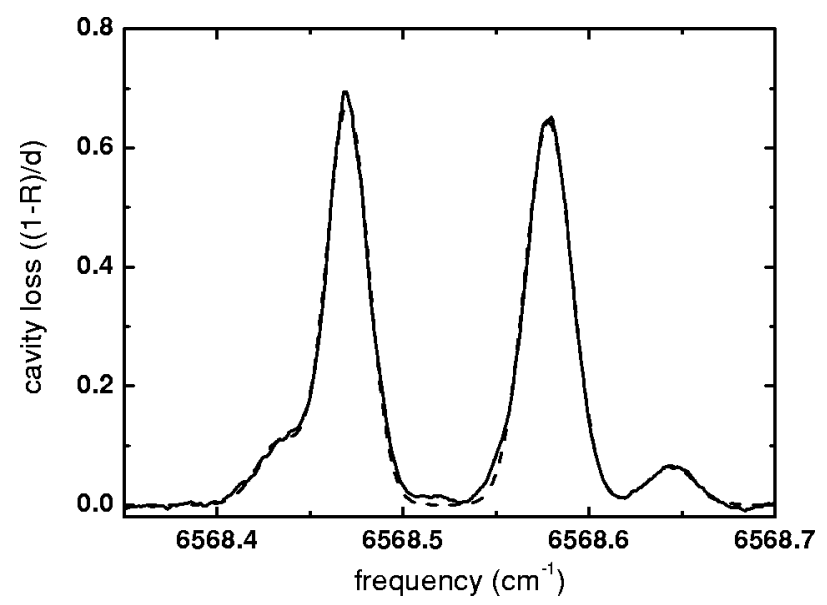

FIG. 1. Typical $\mathrm{NH}_{3}$ CEA spectrum measured in a vessel in which plasma expands that is created from a $\mathrm{N}_{2}-\mathrm{H}_{2}$ mixture. The dashed line is a fit assuming four Gaussian line profiles. The plasma is created in a cascaded arc that operates at a pressure of about $0.5 \mathrm{~atm}$. and a current of $55 \mathrm{~A}$. The background pressure was $20 \mathrm{~Pa}$.

and partially ionized $(5 \%-10 \%)$ nitrogen flow. The hydrogen molecules were injected into the vessel at a flow rate, $\phi_{\mathrm{H}_{2}}$, between 0 and $1.45 \mathrm{slm}$. The background pressure is kept constant by controlling the pump speed. The absolute density of ammonia as a function of the relative flow rate of hydrogen with respect to the total flow rate is shown in Fig. 2 for a background pressure of $100 \mathrm{~Pa}$. The ammonia density in the background gas reaches a maximum of $2.5 \times 10^{19} \mathrm{~m}^{-3}$ at a $\mathrm{H}_{2}$ flow rate of 0.25 times the total flow rate. The increase and saturation can be understood by noting that the hydrogen molecules can only be dissociated by the $\mathrm{N}^{+}$ions from the arc delivering two $\mathrm{H}$ atoms via the reactions $\mathrm{N}^{+}+\mathrm{H}_{2} \rightarrow \mathrm{NH}^{+}+\mathrm{H}$, followed by dissociative recombination of $\mathrm{NH}^{+}$, forming $\mathrm{N}$ and $\mathrm{H}$. Then the $\mathrm{H}$ production will increase with $\mathrm{H}_{2}$ flow until all $\mathrm{N}^{+}$ions are consumed. This explains the saturation behavior of the ammonia density as can be seen in Fig. 2. Under the condition of maximum $\mathrm{NH}_{3}$ production, $0.2 \%$ of the background gas is $\mathrm{NH}_{3}$, independent of the background pressure over the measured range, i.e., from 10 to $200 \mathrm{~Pa}$. Starting from atomic radicals, vol-

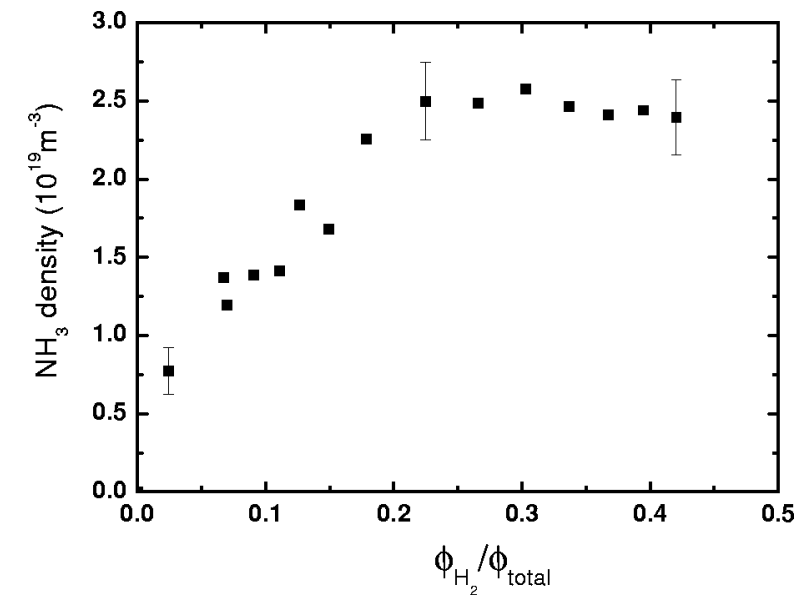

FIG. 2. Density of ammonia as a function of the hydrogen flow rate relative to the total flow rate of nitrogen and hydrogen. The nitrogen is applied through the arc, while the hydrogen is injected directly into the vessel into which the nitrogen plasma expands. The background pressure is kept con-

stant at $100 \mathrm{~Pa}$ the light hydrogen atoms diffuse out of the jet, while the
Downloaded 16 Mar 2005 to 131.155.108.252. Redistribution subject to AlP license or copyright, see http://apl.aip.org/apl/copyright.jsp

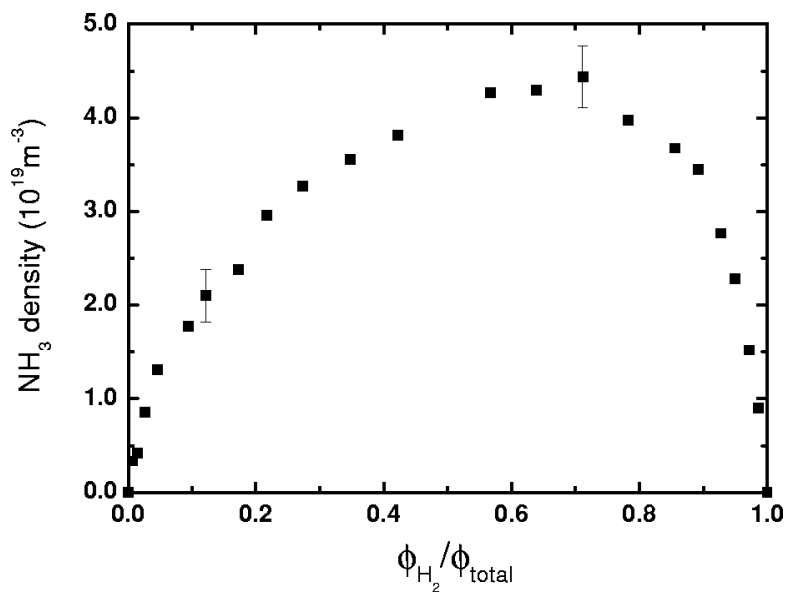

FIG. 3. Density of ammonia as a function of the hydrogen flow rate relative to the total flow rate of nitrogen and hydrogen. Both nitrogen and hydrogen are applied through the arc at a total flow rate of $2 \mathrm{slm}$. The background pressure is kept constant at $20 \mathrm{~Pa}$.

ume production of $\mathrm{NH}_{3}$ would require more reactions and/or three particle association reactions. However, these reactions are slow for the present pressure range. Also the production would show a stronger than linear dependence on pressure, which is not observed.

In the second situation, the same experimental settings were used as in the first situation, except that the hydrogen flows through the arc while nitrogen molecules are injected into the vessel. In this case no $\mathrm{NH}_{3}$ was detected. Note that with $\mathrm{H}_{2}$ in the arc the ionization degree is substantially less, and thus less $\mathrm{N}$ radicals are produced. This shows the importance of the need for atomic radicals in the production of $\mathrm{NH}_{3}$.

In the third situation, the highest efficiency of ammonia production is reached, i.e., when plasma is produced in the cascaded arc with both nitrogen and hydrogen flowing through the arc. In Fig. 3. the results are shown of the ammonia density as function of the relative $\mathrm{H}_{2}$ flow rate to the total flow rate, which was $2.0 \mathrm{slm}$. The maximum ammonia density under these plasma conditions is achieved at $\phi_{\mathrm{H}_{2}}$ $=1.44 \mathrm{slm}$ and $\phi_{\mathrm{N}_{2}}=0.56 \mathrm{slm}$, which is close to the stoichiometric ratio of hydrogen and nitrogen in $\mathrm{NH}_{3}$. This indicates that for both nitrogen and hydrogen the dissociation degree of the thermal plasma source does not depend strongly on the $\mathrm{N}_{2} / \mathrm{H}_{2}$ flow ratio. The maximum density of $\mathrm{NH}_{3}$ at $20 \mathrm{~Pa}$ background pressure is about $4 \times 10^{19} \mathrm{~m}^{-3}$, which is $2 \%$ of the background gas at a temperature of $600 \mathrm{~K}$. This temperature is determined from the width of the measured $\mathrm{NH}_{3}$ transitions. For these experiments the density of ammonia shows a slightly less than linear dependence on background pressure.

We conclude that under our experimental conditions $\mathrm{NH}_{3}$ is mainly produced at the vessel wall. This has also been concluded from a self-consistent kinetic model, ${ }^{9}$ which predicted fairly well the measured relative $\mathrm{NH}_{3}$ density as a function of the $\mathrm{H}_{2}$ percentage in a low-pressure $\mathrm{N}_{2}-\mathrm{H}_{2}$ flowing discharge. ${ }^{10}$

For the efficient production of ammonia the hydrogen and nitrogen atoms have to arrive at the same area on the vessel wall. ${ }^{11}$ However, due to the large difference in mass, the light hydrogen atoms diffuse out of the jet, while the AIP license or copyright, see http://apl.aip.org/apl/copyright.jsp 
nitrogen atoms tend to stay closer to the axis. This so-called mass-defocusing effect has been reported in $\mathrm{Ar}-\mathrm{H}_{2}$ and pure $\mathrm{H}_{2}$ plasma expansion. ${ }^{12,13}$ In view of this effect the production efficiency of $2 \%$ is remarkably high.

We have shown that by using high fluxes of atomic nitrogen and atomic hydrogen radicals, produced from $\mathrm{N}_{2}-\mathrm{H}_{2}$ plasma, ammonia is produced at the vessel wall. Since the plasma is used to produce the radicals, and the wall acts as catalyst, the process is called plasma-activated catalysis. By tuning the plasma parameters and choosing the right wall material, the process could be a promising new way for small scale selective production of molecules, starting from their atomic constituents. It could be extended to hydrazine $\left(\mathrm{N}_{2} \mathrm{H}_{4}\right)^{1}$ or even organic molecules like methanol. In the latter example one could start from natural gas and oxygen. ${ }^{14}$

This work is part of the research program of the "Stichting voor Fundamenteel Onderzoek der Materie (FOM)," which is financially supported by the "Nederlandse Organisatie voor Wetenschappelijk Onderzoek." Dr. R. Peeters and Professor Dr. G. Meijer from the University of Nijmegen and the FOM institute "Rijnhuizen" are acknowledged for their help during the initial phase of the experiment and lending the authors the laser equipment.

${ }^{1}$ E. N. Eremin, Russ. J. Phys. Chem. 49, 1112 (1975).

${ }^{2}$ H. Uyama and O. Matsumoto, Plasma Chem. Plasma Process. 9, 13 (1989).

${ }^{3}$ M. C. M. van de Sanden, J. M. de Regt, G. M. Jansen, J. A. M. van der Mullen, D. C. Schram, and B. van der Sijde, Rev. Sci. Instrum. 63, 3369 (1992).

${ }^{4}$ R. Engeln, G. Berden, R. Peeters, and G. Meijer, Rev. Sci. Instrum. 69, 3763 (1998).

${ }^{5}$ R. Peeters, G. Berden, A. Apituley, and G. Meijer, Appl. Phys. B: Lasers Opt. 71, 231 (2000)

${ }^{6}$ G. Berden, R. Peeters, and G. Meijer, Chem. Phys. Lett. 307, 131 (1999).

${ }^{7}$ L. Lundsberg-Nielsen, F. Hegelund, and F. M. Nicolaisen, J. Mol. Spectrosc. 162, 230 (1993).

${ }^{8}$ HITRAN (high resolution transmission molecular absorption) database (http://www.hitran.com).

${ }^{9}$ B. Gordiets, C. M. Ferreira, M. J. Pinheiro, and A. Ricard, Plasma Sources Sci. Technol. 7, 379 (1998).

${ }^{10}$ J. Amorim, G. Bavarian, and G. Sultan, Appl. Phys. Lett. 68, 1915 (1996).

${ }^{11}$ C. Zhang, Z.-P. Liu, and P. Hu, J. Chem. Phys. 115, 609 (2001).

${ }^{12}$ S. Mazouffre, M. G. H. Boogaarts, J. A. M. van der Mullen, and D. C. Schram, Phys. Rev. Lett. 84, 2622 (2000).

${ }^{13}$ S. Mazouffre, P. Vankan, R. Engeln, and D. C. Schram, Phys. Rev. E 64, 066405 (2001).

${ }^{14}$ C. E. Taylor and R. P. Noceti, Catal. Today 55, 259 (2000). 